up-to-date reference work. But the book almost sinks under its own weight (nearly six pounds!). Will students be able to follow the concepts through the plethora of detail? It was the authors' intention to produce a work of about 400 pages. "Obviously, we were unable to do that." Obviously, but what a pity. Pruning of much fringe material would have let the linking ideas emerge more vividly.

The cladistic approach to the treatment of relationships is carefully explained and is welcome. Page references in the index in bold type show where a definition of the term is to be found, so combining an index with a glossary - another good idea. The illustrations (mainly by Nancy Haver) are excellent and plentiful and a wide selection of references is given at the end of each chapter.

With perhaps even more information than in R.D. Barnes' Invertebrate Zool$o g y$, and with the 'threads of continuity' so well thought out, Invertebrates deserves to succeed; but to get the most out of it in terms of unifying concepts rather than detailed facts, students will need to read it with great care and selectivity.

Alan Brafield is in the Division of Biosphere Sciences, King's College London, Campden Hill Road, London W8 7AH, UK.

\section{Forest matters}

\section{Kenneth Mellanby}

Global Forest Resources. By Alexander S. Mather. Belhaven: 1990. Pp. 341. $£ 40$.

Australlan Tropical Rainforests. Edited by L J Webb \& J Kikkawa. CSIRO Publications: 1990 . Pp. 185. \$55.

THE importance of the world's forests is becoming increasingly understood. They produce timber for buildings and furniture; fuelwood is the main energy source for much of the world's population; they provide food, both animal and vegetable, and an increasing number of drugs and other chemicals. Conservationists stress the importance of the vast diversity of species, many of which have not yet been identified, to be found in tropical forests. Woodland is increasingly used for recreation in developed countries.

The destruction of forests, liberating carbon dioxide when the wood is burned, and reducing the uptake of that gas by growing trees, contributes to the buildup of the so-called greenhouse gases. Although forest clearing has produced much of the world's farmland, so allowing food production to keep up with population growth, recent felling in the tropics, like some deforestation in North America in the nineteenth century, has resulted in erosion, soil degradation and flooding. In

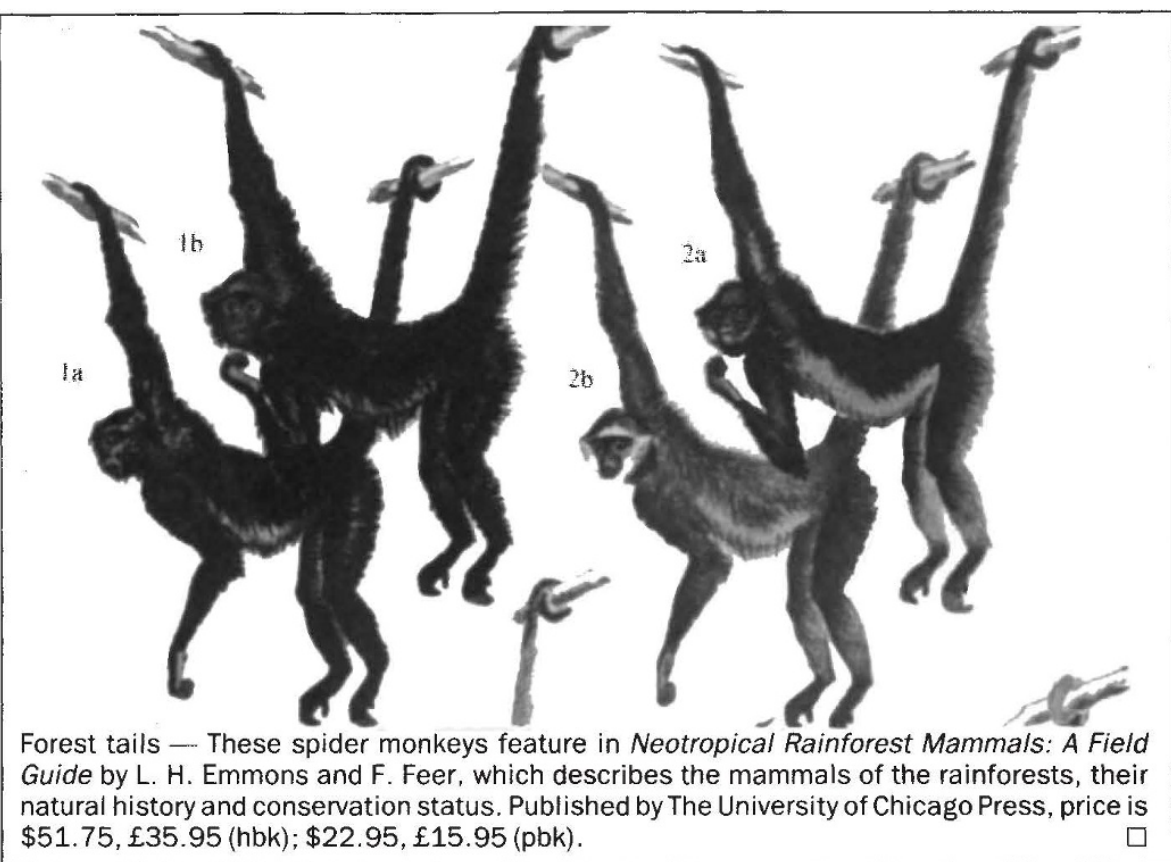

his book The Ages of Gaia, James Lovelok has suggested that tropical forests affect global climate, and that their loss could have results even more serious than those foretold for the greenhouse effect.

Alexander Mather does not underestimate the losses that have occurred, from the Neolithic period onwards. The effects of forest clearances round the Mediterranean in the time of the Roman empire have had permanent results on many countries, once fertile and now semidesert. In Britain, forest areas in 55 BC when Julius Caesar invaded the country were smaller than today. Notwithstanding accelerated deforestation in many areas, Mather records that "as much as 80 per cent of the [world's] pre-agricultural forest survives". This situation is not one to encourage complacency, but it does suggest that increased efforts to preserve our remaining forests are still very much worth while.

Mather shows how, in developing countries, after a period of destruction, there is often a 'steady state' where new planting is a least equal to the areas being cleared. But much of this planting is of quick-growing exotic species. Thus Australian Eucalyptus species are the commonest trees in large parts of Africa, South America and China, and American Sitka Spruce has contributed largely to new planting in Europe. These new plantations are more satisfactory to foresters than to ecologists, who deplore the loss of ancient woodlands and the virtual disappearance of virgin forest from developed countries.

In Global Forest Resources, Mather gives a succinct account of the world situation. He includes a brief history of forests and their exploitation, and describes in some detail today's position. The possible exploitation of forests on a sustainable basis is the main theme throughout the book. As already mentioned, the use of fuelwood throughout the developing world is a major international problem. We all have had our feeling harrowed by television programmes showing women spending many hours collecting and carrying the twigs that are their only fuel. Planting in areas of shortage are not always successful in the most affected areas, where drought is frequent. However, in other parts of the world 'biomass' is increasingly realized to be an important source of energy, and as it recycles the carbon dioxide absorbed by fuel trees it makes no net contribution to greenhouse gasses.

The Australian Tropical Rainforests of Queensland, described by 22 experienced Webb and J. Kikkswa, can be considered a special case illustrating some of Mather's points. The main purpose of this book, however, is to draw attention to the value of the forests described. North Queensland's rainforest is "the only part of mainland Australia that has persisted continuously as wet tropics for the last 65 period)". Its interest value economically, scenically and even spiritually is the theme of the writers. They are also concerned with the dilemma of whether to permit selective logging of valuable trees for timber. This has been suggested as the only economic alternative to total clearance. Most of the authors consider that any exploitation would be damaging, and that these unique forests are so important that they should be strictly preserved for posterity.

Kenneth Mellanby is at 38 Warkworth Street, Cambridge CB1 1EG, UK and was formerly director of Monk's Wood Experimental Station. scientists in the volume edited by L. J. million years (since the Cretaceous 